DEPARTMENT OF THE INTERIOR

UNITED STATES GEOLOGICAL SURVEY

\title{
MAP OF SEDIMENTARY BASINS OF THE INDONESIAN REGION
}

\section{By Warren Hamilton}

PREPARED ON BEHALF OF THE MINISTRY OF MINES, GOVERNMENT OF INDONESIA AND THE AGENCY FOR INTERNATIONAL DEVELOPMENT, U.S. DEPARTMENT OF STATE IN COOPERATION WITH THE GEOLOGICAL SURVEY OF INDONESIA 